\title{
A Generation of Promise: The 1908 Junior National Scholarship Candidates - Education, Occupation, and the First World War
}

\author{
JANE LATCHEM
}

\begin{abstract}
The Junior National Scholarship examination was introduced in the early twentieth century to encourage able children to continue at school through to secondary level. This article investigates the extent to which successful candidates of 1908 took the opportunity for further education beyond primary school. The main focus is on those who went on to university study and pursued successful careers, but those who ended up in less enviable circumstances are also of interest. Also highlighted are the differing vocational opportunities available to girls and boys, the importance of teaching as a career for girls, and the effect on the boys of the First World War.
\end{abstract}

On 9 December 1908, 1,765 children gathered at schools across New Zealand to sit the two-day Junior National Scholarship examination. ${ }^{1}$ Most were 12 or 13 years old. ${ }^{2}$ Those who passed would gain a free place in a secondary school, district high school, or technical high school and would also be eligible for either a national scholarship or a scholarship from their local education board. Such opportunities were prized. From 1905 to 1908, just over half the number of primary school leavers left school without having passed the examination for Standard 6. ${ }^{3}$ In 1908, 147,000 children attended New Zealand public primary schools but only 8,600 attended secondary schools. ${ }^{4}$ Of those who went on to secondary education, only a small percentage completed a full five-year course of tuition. ${ }^{5}$ A system of junior and senior national scholarships was initiated in 1903 to encourage able children from families of "limited means" to aim for full participation in secondary schooling. ${ }^{6}$ The Minister of Education, Premier Richard Seddon, believed that education was the key to New Zealand's future prosperity and place in the world. "When the best minds of a nation guide its destinies", declared Seddon, "that nation is bound to hold an exalted position." Seddon wanted to see "master minds ... at the command of commerce and politics."7 Although Seddon had been a poor scholar, ending his formal education at 12, as Minister of Education the value to the nation of a well-educated population was clear. ${ }^{8}$

This essay originated from curiosity about the names of scholarship candidates published in the New Zealand Gazette on 28 January 1909. ${ }^{9}$ Who were these young scholarship-sitters? Did the opportunity for further education at secondary level transform their lives? How many went beyond secondary school to university, and what sort of occupations did they engage in eventually? Did this early public examination success lead to greater successes, and did any individuals among the group become well known for their later achievements? The boys reached serving age during the First World War; how did they fare? Was New Zealand a land of opportunity for those with intelligence and drive, irrespective of family background? If education was a path to social and occupational mobility, what kind of ladder to future success did high marks in the Junior National Scholarship examination provide?

The scholarship candidates of 1908, born in the mid 1890s, grew up in a time of relative prosperity. ${ }^{10}$ The Liberal government (1891-1912) instituted a wide range of economic, constitutional, welfare, health, and educational policies. Among the education reforms were 
measures aimed at expanding access to post-primary education, particularly for children from poorer families. The Junior National Scholarship examination was one example. For Seddon, the state had an essential role in ensuring that "poor children who are endowed by Nature with brains have an equal opportunity of using them to advantage." ${ }^{11}$ But Seddon was also aware of the wide appeal of such policies and pursued them as much for their electioneering value as for the sake of much-needed reform. ${ }^{12}$ Another supporter of broadening access to secondary schooling was Inspector-General of Education George Hogben who had long battled to reform the education system. Hogben introduced technical high schools, a more practical or vocational option for the less academically-able. He tried to encourage district high schools to offer manual and commercial instruction and an agricultural focus in rural schools. Hogben's plans met strong and unexpected resistance, however, from schools and parents who valued an academic curriculum as a crucial stepping-stone for those aspiring to university study and professional or government employment, and rural parents who wanted their children to be able to compete fairly with urban children. ${ }^{13}$ These, and other issues such as raising the age for compulsory attendance, social class, gender, eugenics, and the integration of Māori pupils into the mainstream state school system meant that post-primary education was a heavily contested sphere during the 1900s and 1910s.

There may have been Māori pupils among these scholarship candidates but no evidence of any was found. The Native School system, which ran from 1865 until 1967, educated Māori children at the primary level. Those who sought secondary education could board at one of the denominational secondary schools for Māori. ${ }^{14}$ The denominational schools operated their own secondary and tertiary scholarships, for example, the Te Makarini scholarships associated with Te Aute College. ${ }^{15}$ From the early 1900s, more Māori children attended state primary schools than Native village schools so it is possible that some Māori pupils may have been among the 1,765 sitting for the 1908 scholarship. ${ }^{16}$ But Māori pupils such as Joseph Clark, who won a Te Makarini senior scholarship in 1906 and who was also known as Hōhepa Karaka, would have been very difficult to differentiate from Pākehā pupils on a list of candidates. ${ }^{17}$

The range of occupations available to school-leavers was also expanding, and included the white-collar sector. ${ }^{18}$ For girls, these changes were especially welcome. Many young women opted for the new possibilities, particularly office work, ${ }^{19}$ and doors began to open a little wider to a limited range of professional careers. From the early 1900s, however, a debate brewed over what constituted a suitable curriculum for adolescent girls. Margaret Tennant related how concerns that girls" "weaker" constitutions not be over-taxed by academic schoolwork and by competition with boys led to the introduction in 1917 of domestic science as a compulsory subject for Form 3 and 4 girls ("junior free place scholars") at secondary school. ${ }^{20}$ At the same time, the measure addressed the concerns of supporters of eugenics who, as Kay Morris Matthews noted, saw education as the means to "equip women better for their preordained roles as wives and mothers." 21 The new subject took the place of more academic topics, especially sciences, making it harder for later generations of girls to gain knowledge essential for study at university. Nevertheless, the introduction of the new discipline into university colleges brought opportunities for women, as Tanya Fitzgerald and Jenny Collins' research on New Zealand home scientists showed. ${ }^{22}$ For boys too, a good education opened up a broader span of employment opportunities. Those who explored knowledge pathways such as further education and apprenticeships enhanced their "life chances" and increased their opportunities for upward occupational mobility. ${ }^{23}$ Success for the scholarship candidates has been assessed through the lenses of post-secondary education and later occupations. 
The focus on successful individuals, however, should not ignore the fact that occupational and social mobility could be downward too, as Melanie Nolan pointed out. ${ }^{24}$

Uncovering details of lives begun in the late nineteenth century was not expected to be a straight-forward task. Each of the 645 names on the list of passing students published in 1909 was investigated for further information to shed light on their subsequent lives and careers. The following method was applied. Because the 12- to 13-year-old boys who sat the scholarship examination in 1908 reached fighting age during the First World War, the Auckland War Memorial Museum's Cenotaph database was consulted first. ${ }^{25}$ Cenotaph proved a particularly rich source. In many cases it was possible to quickly confirm that the right person had been found. Basic biographical information from army enlistment forms provided varying levels of detail, often including pre-war occupation, address of next-of-kin, whether the man had survived the war, and if not, when, where, and how he had died. ${ }^{26}$ Cenotaph searches often yielded middle names, aiding subsequent inquiries. While this source helped trace boys, further searches were the same for both girls and boys. The second step was to search Archives New Zealand's Archway database. Useful information in the form of military personnel files and probate records was often available. Many military personnel files were downloadable, supplying valuable corroborating information. This "secondary contextual information," as David Hood termed it, proved highly important as an aid to identification. ${ }^{27}$ The third source was the National Library's digitised newspapers site Papers Past. The Library's Tapuhi database of manuscripts and archives was helpful in a small number of cases in providing additional biographical details. Finally, a Google search sometimes revealed web pages with useful information, such as Capital and Coast District Health Board's history pages. ${ }^{28}$ By evaluating the results of all these searches, it was often possible to build a basic outline of the later lives of many on the list.

It is only the existence of online tools such as these databases that makes a project of this kind viable. Their capacity to search for names across large volumes of data permits systematic analysis in a way not possible previously. The first section of this essay looks at background issues around the Junior National Scholarship and describes the problems encountered in answering the questions of the research. The second section focuses on the candidates' university attendance, their occupational endeavours, and the effects on the boys of the First World War. Individuals will be identified by their first and last names, and by the appending of their rank on the list, for example, Johanna Brosnan [22]. The essay concludes with a brief survey of high-achieving individuals among the 1908 scholarship candidates, as well as some whose lives turned in unexpected directions. Over 100 years later, a surprising number could be traced to some degree, with many achieving noteworthy success. This essay seeks to discover whether any of these promising youngsters became the leaders - the 'master minds'-Seddon hoped for.

The Junior National Scholarship came into existence with the National Scholarships Act of 1903. The Act's purpose was to bring "higher education within the reach of deserving scholars." 29 The scholarship examination was to be undertaken by talented pupils not over the age of 14, who had attended school in New Zealand during the preceding three years, and who had been instructed in the subjects of Standard 5 or higher. The sum of $£ 10$ was payable to scholarship winners, as well as any tuition fees charged by a secondary school; those who had to live away from home received another $£ 30$ annually. To ensure scholarships were won by the "deserving," those whose parents" annual income was more than $£ 250$ were disqualified, although they were still eligible to win a 
free place at a secondary school. By 1909 scholarships were allotted for every 4,000 children or part thereof in an education district, and the examination was based on the Standard 6 syllabus. ${ }^{30}$

Over the course of two days children were tested on their knowledge of English, arithmetic, geography, history, and elementary science, as well as general knowledge and ability at drawing. Scored out of a possible 800, the pass mark was 400. Because the contents of the 1908 examination paper could not be found, the following details pertain to the 1909 tests. The 800 marks were allotted thus: English (300), arithmetic (200), and 100 each for geography, drawing, and the general paper. The general paper consisted of questions on history, elementary science, and general knowledge, while drawing was split between drawing with instruments and drawing with a pencil or brush. To pass, a minimum of 75 marks for English and 50 for arithmetic was stipulated. ${ }^{31}$ According to teachers, the level of the examination was set very high. It was common for pupils attempting to win scholarships to receive extra tuition, sometimes to the extent of one or two hours each school day, beginning as early as July. ${ }^{32}$ The examination could be attempted more than once. Among the top 20 on the 1909 Gazette list, nine had sat the examination the previous year. ${ }^{33}$ Sixty percent of the 645 candidates were male. Further information was found on 460 (71 percent); of which, 330 were boys. In 1909 the top three place-getters were girls, with the highest mark of 661 awarded to Dorothy Hardcastle [1] of South Canterbury.

The full list of examination results published in the Gazette and in newspapers around the country did not show which candidates would receive the small number of scholarships. That was assessed by regional education boards and depended upon satisfaction of the age and parental income qualifications. The restrictions meant that Dorothy Hardcastle, "though top on the list for the Dominion, could not receive a national scholarship on account of the income bar imposed under the Act." Instead, she received a $£ 7$ scholarship from the local education board. ${ }^{34}$ Only a single scholarship could be awarded to any one school. The Act also stipulated that qualified candidates from schools with fewer pupils were to receive a specified level of preference to ensure that children from smaller schools were not disadvantaged. ${ }^{35}$

While children from well-off families would not qualify for a scholarship, many entered the examination to try to win a free place at a secondary school, and for the prestige, competing with children from poorer families. Evidence found about 16 candidates showed a wide range of family backgrounds. Among the 1908 candidates were the children of a hairdresser (Horace Larking [111=]), a brick-layer (Elizabeth Gibson [261=]), a shipwright (Theodore Gibbs [363=]), a farmer (Frederick Hanson [431=]), and a post-master (Harold Bennetts [431=]). Hugh Somerset's [499=] father was a blacksmith and freezing works maintenance engineer, and Douglas Ball [114=] was the son of a journalist. Two were the children of teachers (Graham Parkinson [166=] and Karl Kippenberger [177=], and two had fathers who were drapers (Doris McClurg [3] and Leonard Bestall [261=]). It is unclear whether these candidates' families were poor and struggling financially or somewhat comfortably off. Others, however, were probably among more affluent New Zealand families. There were, for example, the children of a barrister (Norman Richmond [224=]), a veterinary surgeon (Richard Kinloch $[70=]$ ), a clothing manufacturer (Effie Cathie [134=]), and a member of parliament (Clutha Mackenzie [57=], whose father Thomas was briefly Premier during 1912). ${ }^{36}$ Enid Whitelaw [632=] and other members of her apparently wealthy family were mentioned frequently in the "Social Sphere" pages of Auckland's Observer newspaper. ${ }^{37}$ The parental income qualification was removed in $1910 .{ }^{38}$ It appears that, by this time, efforts to target scholarships toward poorer children were waning. Earlier that year, school inspectors supported increasing eligibility for the scholarships so as to "cast the net as widely as possible" to identify the "best brains in the country" and "train them up for the benefit of the 
state." 39 At the same time as the income qualification was withdrawn, the scholarship was opened up to pupils at private schools.

Although the search method was useful in highlighting some of the major events in the candidates' lives, there were limitations. Cenotaph still has gaps in its record. While Archway's downloadable military personnel files were very beneficial, many are not yet viewable online. Probate files did not always provide an occupation. Sometimes so many records were returned for a particular set of names that it was impractical to examine all of them and difficult to ascertain which, if any, were relevant. Papers Past's optical character recognition is very good but not perfect. There were cases when a substantiating entry was not returned by a search, but appeared in a later search for another person. These databases are not stable, because data continues to be added. If the searches were repeated it is likely that more information about more of the candidates would be uncovered. And Google searches were helpful in only a few cases where a person was reasonably well known in some sphere or mentioned on a family history website. ${ }^{40}$

Other difficulties were caused by the nature of what was sought: names. Misprints, misspellings, and reversal of order of names were fairly common. For example, Nora Angland's [130=] first name was Honora; Ivor Pritchard's [183=] surname should have been spelt "Prichard"; and Ashley A. Wilkinson [239=] was usually known as Allan (and sometimes Alan) Ashley Wilkinson. A few names initially left the person's gender unclear, such as Vivian Barton [261=], whose military personnel file settled the matter, and Theo Clouston [355=], who attended Nelson Girls' Central School. ${ }^{41}$ Other names were simply too common, and those that lacked a middle name made it very difficult to establish a firm connection. Cenotaph, for example, provided four records for "Ernest Wilson" [512=]; five for "Alexander Milne" [638=], and six for "William Davis" [258=], none with middle names. By checking details from downloadable military personnel files and Cenotaph records, it was possible to narrow it down in the cases of Wilson and Davis. But generally for those with common names, the results were too often of dubious reliability and such cases were categorised as untraceable.

An illustration of the difficulty in identifying people on the list can be seen in the case of Karl H. Kippenberger [177] of the North Canterbury education district. A search using Archway returned three probate files, all from the 1950s. These were for Karl, a retired farmer from Waimate, and two with no occupation shown: Karl Henry and Howard Karl. Cenotaph's sole Karl Kippenberger turned out to be the Second World War military leader Major-General Howard Karl Kippenberger (1897-1957). Denis McLean's biography of “Kip," as he was widely known, described his early life in rural North Canterbury where he won a scholarship to secondary school, his First World War service, and qualification as a solicitor in 1920 and as a barrister in 1926. McLean explained that although "Kip" had been baptised "Karl Howard", he was known as "Howard" from an early age to differentiate him from his father, also Karl. He entered his name as Howard Karl on his army enlistment form, and this order persisted for the rest of his life. ${ }^{42}$ Comparatively little could be discovered about Karl Henry other than that he attended Otago University College during 1914 and ended his working life in Wairoa as a company manager. A 1924 list of teachers included a Karl Kippenberger. ${ }^{43}$ Either of these men could have been the Karl H. Kippenberger on the 1909 Gazette list, but only one has the requisite North Canterbury background and a verified date of birth, one that places him in the right age group: Howard Karl Kippenberger. $^{44}$

Girls were more difficult to trace than boys, particularly once they had left school. ${ }^{45}$ Those who did not attend university or become teachers were largely without a presence in newspapers, which published lists of results from Senior National Scholarship, Junior and Senior Civil Service, 
teacher certification, and university examinations. Most girls married and changed their surnames. ${ }^{46}$ Only the marriages of those whose families were sufficiently socially prominent featured in newspapers. ${ }^{47}$ Once married, girls generally gave up work outside the home and were unlikely to be mentioned in newspapers. But without the Cenotaph database and Archway's downloadable military personnel files, it would have been similarly difficult to discover much about most of the boys. It is likely that some untraceable candidates moved to Australia or elsewhere beyond New Zealand, such as Harlequin Huxtable [595=] ${ }^{48}$ and Eric Battershill [532=] who served in Australia's armed forces, and Norman Gadsby [546=] who made his career as an obstetrician in Scotland but maintained links with New Zealand. ${ }^{49}$

Because the scholarship candidates were amongst the brightest of their age group, and because some did take up scholarships for further study, a significant proportion studied at one of the university colleges. Just as secondary school was attended by only a small percentage of pupils, university study was the privilege of even fewer. In 19192,961 students attended lectures at all four of New Zealand's university colleges, up from 1,936 in 1915, and 1,493 in $1908 .{ }^{50}$ Of the 330 boys, 81 are known to have attended university, with 61 graduating. Another 27 entered the ranks of the accountancy, surveying, architecture, and engineering professions. While no evidence was found of their attendance at a university, their professional training has been treated as equivalent to tertiary study. Including the qualified professionals, 32 percent of the 330 young men undertook tertiary education and, of these, 82 percent completed a degree or high-level professional qualification. Many of these university students had their studies interrupted by war service; seven died. ${ }^{51}$ Prior to the war, in 1912, women made up 31 percent of students attending lectures. By 1917, and during 1918, this had increased to 47 percent, but in 1919 dropped to 38 percent as returning soldiers resumed their studies. ${ }^{52}$ Many women attending university during the war years would have had the experience, for a short while, of forming almost half the student body. ${ }^{53}$ Among the 130 girls, 48 (37 percent) attended university, with 27 completing a degree. The 27 degree-holders included 13 Masters of Arts, two Masters of Science, and one Bachelor of Medicine and Surgery. ${ }^{54}$ Ruth Fry's summary of 1925 secondary school-leaver destinations showed that only three percent (both male and female) headed to university. Another seven percent of boys trained in the architecture, surveying, and engineering professions, while four percent of boys and seven percent of girls taught or attended training college. ${ }^{55}$ From the candidates' high level of participation in tertiary study, it seems likely that many would have striven towards higher status occupations.

The occupational categories devised by Erik Olssen and Maureen Hickey were used to group individuals according to the nature of their work. Due to the relatively small and incomplete amount of data gathered, the groupings were made irrespective of whether an individual's occupation was their first workforce experience or their last. ${ }^{56}$ Olssen and Hickey's main categories were: large employers and managers (1); professionals (2); semi-professionals (3); small business owners and self-employed (4); minor officials and supervisors (5); white-collar (6); skilled (7); semi-skilled (8); unskilled (9); and rural (16). For many of the boys, their only known occupation was the one recorded on their army enlistment documentation. In other cases, the sole known occupation was that denoted on a probate file. That occupation might not be reflective of a lifetime's participation in the workforce. Nor would it indicate their level of attainment necessarily. The descriptions "civil servant" and "public servant", for example, which were the only known occupations of 12, could equally encompass a low-level position and a senior figure in a government department. Nevertheless, with little else to go on, these designations provide a sense of what they may have been aiming for, especially for those whose only known job was one 
performed at the beginning of their working life. Where more than one occupation was found, generally the later one was selected as representative of the direction they might have been aiming toward. ${ }^{57}$ Those whose only known occupation was law clerk, law student, medical student, or student have been counted among the professionals, because for some, these were the only signposts available for the career they were embarking on. Another factor is that individuals who died during the war often had only a low-level occupational designation. What they may have achieved, given the opportunity, can only be speculated.

Information about the types of employment taken up by the girls was fairly sparse, but details were found for 101 of the 130. Teaching was the career of choice among the girls on the list, with 88 teachers in the semi-professional category. White-collar office workers numbered 10. Women had begun entering the realm of the office before the First World War but, with tens of thousands of men joining the army, increasing numbers of women became clerks, typists, and stenographers. ${ }^{58}$ Women generally took over the lower level and repetitive tasks that men were happy to give up. ${ }^{59}$ As Erik Olssen has noted, most women's participation in the labour force at the time was seen as "an interlude between school and marriage." ${ }^{60}$ In 1921, when most of the female candidates were around 26 years of age, only 21 percent of New Zealand women were in paid employment. ${ }^{61}$ Female professionals were rare; university lecturer Mary Turnbull [33=] and doctor Grace Kime [28=] were the only known professionals in this cohort. Turnbull's university career commenced immediately upon her graduation with a Masters degree in classics in 1917. Promotion took longer, however, with a lectureship in 1930 and senior lectureship in $1948 .^{62}$ Although Kime was Medical Superintendent at Waimarino Public Hospital in 1925, she could not perform major operations, presumably because she had trained as a general practitioner, rather than as a surgeon. ${ }^{63}$ As Olssen and Hickey observed, "women entered the semi-professions much more easily than the professions." ${ }^{\prime 4}$ Women medical graduates found actually practising medicine more difficult, because opportunities were restricted and low-level, and prejudice common. ${ }^{65}$

Teaching, however, was considered a particularly suitable job for women: a reassuringly feminine occupation in keeping with women's customary function as educators within the family. It was seen, as Beryl Hughes put it, "as an extension of women's traditional and approved role of looking after other people." 66 And, unlike other occupations, teaching could be combined with university study, allowing students a means of earning a living at the same time as undertaking their training. ${ }^{67}$ Of the 28 female graduates, 19 became teachers. From the 1890 s until well into the second half of the twentieth century, most women students graduated with arts degrees and became teachers. ${ }^{68}$ A small number who were highly qualified, such as Dorothy Hardcastle [1], taught in secondary schools. ${ }^{69}$ Although teaching was demanding, especially for those in solecharge positions, it was also the most desirable career for many women. Most taught for probably only a few years until marriage, but of the 88 teachers in this group 15 had life-long teaching careers and another nine probably did so also. Most of the 15 had not married. The other nine became teachers when they left school and, while their probate occupations were recorded as "spinster," it seems likely they also would have continued teaching as it was their best means of support. ${ }^{70}$ Education provided an opportunity for academically capable girls to aspire to more stimulating occupations; teaching allowed them the prospect of a fulfilling career and a respected position in the community. ${ }^{71}$

The boys of the group enjoyed much wider occupational horizons. From the 330 boys, occupational data was found for 301. Of these, 101 pursued a professional career (34 percent), law being the most favoured, with 30 practitioners. Other professions included medicine, engineering, surveying, accountancy, and architecture. ${ }^{72}$ The second most common grouping was that of the 
white-collar workers, mostly clerks and civil servants, numbering 75 ( 25 percent). Third were the 48 semi-professionals (16 percent), mainly teachers but also draughtsmen, bank officers, journalists, and clergymen. The fourth-largest category was for rural occupations, with 31 (10 percent). Ten (three percent) were managers or directors of large companies, 10 were small employers or self-employed, and another 10 were skilled manual workers. A further 10 were distributed between three categories: minor officials and supervisors, plus semi-skilled and unskilled workers. Six (two percent) could not be categorised because their occupations spanned two or more groupings and insufficient information was available to determine where they should be placed. ${ }^{73}$

In 1926, skilled, semi-skilled, and unskilled workers formed 54 percent of New Zealand's urban male workforce, with professionals and semi-professionals totaling just seven percent. ${ }^{74}$ With the removal of those with rural, uncategorisable, or unknown occupations, a group of 264 remained. ${ }^{75}$ White-collar workers from the list of candidates comprised 28 percent, compared with 19 percent among the general working population. The 149 boys who reached-or aspired to reach — professional or semi-professional status represented 56 percent of the group, while the 14 skilled, semi-skilled, and unskilled workers formed just 5.5 percent. Thus, a near complete inversion of these two occupational groupings occurred in comparison with the general urban male working population. ${ }^{76}$

While the men were in their early thirties, the Depression struck. During those years it is likely that some of the candidates lost their jobs. Those who were public servants had their incomes reduced by 10 percent in 1931 , and again the following year. ${ }^{77}$ Some may have participated in work relief programmes. Scholarship candidate Horace J. Twining [224=], from the Auckland Education District, was one known to have fallen on hard times. Even before the Depression had taken effect, Twining, a former civil servant, was arrested in Auckland in March 1929 for being "disorderly," a charged he denied. Unable to find work and having not eaten for several days, he was "a pitiable sight" in court, and the judge noted that it "appeared fortunate for him that he was arrested." The court heard that Twining "was once in a good position but for some considerable time past he had been unable to secure work." He had come to Auckland to look for work, and eventually was arrested at midnight, "huddled up" outside the Government Labour Bureau. A Salvation Army officer offered to take care of Twining until he could find work. Twining was reluctant: "I would rather go out to the country and get work and not be a burden on anyone," but he agreed to accompany the officer and was convicted and discharged. ${ }^{78}$ It is not known what happened to Horace Twining after this. Perhaps with a little compassionate support he recovered from his descent into desperation and went on to regain something like his former position.

Was Horace Twining's experience of hard times attributable to a widespread economic depression or simply individual misfortune? While many commentators date the start of the Great Depression to the United States' stock market crash of late October 1929, Twining was arrested six months earlier. The New Zealand economy had been undergoing a severe decline since 1927 and possibly he had been caught up in its effects. ${ }^{79}$ Unfortunately there is no evidence explaining how the one-time civil servant began his downward spiral, although the court recorded that "he had never been in any sort of trouble before." ${ }^{80}$ Archway lists a probate record filed at the Hamilton High Court of a Horace John T. Twining, "pensioner" of Tokanui, who died in 1968. Although he cannot be assumed to be the same person, it is tempting to speculate on that possibility. The Waikato settlement of Tokanui was, incidentally, the site of Tokanui Hospital, that in the 1960s was one of the larger psychiatric institutions in New Zealand. Perhaps Twining had been an inmate of the hospital, or had worked there, and then retired nearby. For many, educational success led to 
expanded occupational opportunities and upward social mobility. While the later course of Twining's life will probably never be uncovered, the report of his arrest and conviction shows that downward mobility was also possible, even among those with favourable early prospects.

But, before most of the boys had embarked on their working lives, the First World War intervened. In August 1914 when the war began, most of these young men were around 18 or 19 years of age; the minimum age for volunteers was 19. ${ }^{81}$ Around 103,000 New Zealanders were sent overseas to fight and approximately 18,500, or just under 18 percent, were killed. ${ }^{82}$ The war was undoubtedly the defining life experience for most of the 330 boys. Of the boys who were traceable, 292, or 88 percent, went to war. Five did not serve with the armed forces overseas, and for 33 (10 percent) no record could be found of army service. Fifty-six of the male scholarship candidates who left New Zealand to fight died during the war, a casualty rate slightly higher than the average, of 19 percent. ${ }^{83}$ One of those who died was Donald Hosie [97], a young Dunedin architect who won a 1916 New Zealand-wide competition for the design of Wanganui's proposed Sarjeant Gallery. He was killed in action at Ypres in October 1917, just three weeks after the foundation stone to the Gallery was laid. ${ }^{84}$ Hosie's death illustrates the large-scale loss of potential to New Zealand of so many men killed in young adulthood.

Of the five who did not go to war, three died before they had the chance to volunteer or be called up. Keith Douglas [465=] died in 1909, barely six months after the examination, when he accidentally shot himself while returning from a hunting foray. ${ }^{85}$ Mechanic, driver, and tourist guide Harold Bennetts [431=] of the Mount Cook Motor Company died in 1914 when he was thrown from a car near Lake Pukaki. ${ }^{86}$ Horace Larking [111=], a Public Works engineering cadet, died in an explosion at an Ōhākune quarry in $1916 .{ }^{87}$ Francis Carson [114=] lost most of his right arm after a printing press accident in $1911 .{ }^{88}$ Quintin Christophers [229=] was called up but only admitted into the Territorials because of older brothers killed in the war in 1915, 1916, and 1917; a fourth brother died in $1918 .{ }^{89}$ Another, George Adair [532=], was to be granted an exemption from service - "if the facts were proved" — as "the only surviving son of military age." 90 The latter cases highlight the war's toll on families throughout New Zealand.

While most of the 292 returned home, for some, their wartime experiences took a severe toll on their health. Clutha Mackenzie [57=] was blinded. ${ }^{91}$ Several suffered gas poisoning. The gassing may have been a contributing factor to Richard Kinloch's [70=] suicide in $1920 .{ }^{92}$ Many soldiers spent time in hospital for a variety of injuries and illnesses. One was Clarence Jackman [261=] who needed treatment for gunshot wounds to his face and leg, and was hospitalised for bronchial pneumonia and gonorrhea, the latter for two months. ${ }^{93}$ Other men had the misfortune to contract tuberculosis while in the army. Thomas Wilson [219=] was treated for the illness in 1917, but Karl Laurenson [424=] ended his days in Waipukurau's Pukeora Sanatorium for Disabled and Tubercular Soldiers, dying in 1923. ${ }^{94}$ While in the trenches at Messines, Allan Macfarlane [313=] received a gunshot wound to the spine, leaving him with both legs paralysed below the knees; he spent at least four years undergoing treatment in military hospitals. ${ }^{95}$ Vincent Jervis [368=], a professional soldier, lost a leg to shell-fire in 1916 but, supplied with an artificial limb, continued his military career until retirement. ${ }^{96}$ For some, the war's effects would linger, affecting them mentally, physically, and emotionally, preventing them from leading the kinds of lives they wanted and forcing them to change course.

Then there is the story of a determined young man who followed his own rather singular course toward success. The endeavours of Eric Battershill [532=] of Hastings twice brought him to the attention of authorities in 1913. In June he was charged with setting up a wireless radio without consent, a particularly worrisome activity because "if done by persons of great intelligence 
for reasons serious to the country and Empire, such as the interception of wireless messages from overseas ... [it] might produce results of the utmost gravity." ${ }^{97}$ In September, however, Eric rescued a drowning boy from a swift-flowing river and was later presented with a Royal Humane Society medal. ${ }^{98}$ When war broke out, he tried to enlist repeatedly but was rejected due to his youth and "a degree of suspicion about his wireless activities." The Minister of Internal Affairs told him that because he "might have been 'communicating with the enemy' he could not be allowed to leave." 99 In the end he overcame this disability by working his passage to Australia, where he jumped overboard with 30 shillings to his name and joined up with the Australian motor transport group. He served in France as wireless operator, despatch rider, intelligence officer, and as a pilot with the Australian Flying Squadron. Battershill continued to study electrical matters in England and worked on large post-war electrical projects. He then teamed up with another pilot on his return to Australia where they launched themselves as "Leslie and Dare," organising entertainment and jazz performances. Battershill won the name "Dare" in a coin toss, his own name being not conducive to a career in show business. Daring by nature, and now "Dare" by name, he performed an aerial stunt in 1922 to publicise his venture, dangling over Sydney from an aeroplane. He resumed his involvement with radio by launching Sydney's first radio broadcasting journal in the 1920s. From there he became a sales manager, and eventually, general manager of an Australian radio manufacturer. This audacious high achiever never returned to being Eric Battershill, formally adopting the name "Dare" and bequeathing it to his children. ${ }^{100}$

A large proportion of the traceable candidates were high achievers, particularly among the 330 boys. Two who stood out were the Second World War military leaders Graham Parkinson [166=] and Sir Howard Kippenberger [177]. Both attained the rank of major-general and were highly decorated. ${ }^{101}$ Another widely known figure was Sir Clutha Mackenzie [57=], Chairman of the World Braille Council. ${ }^{102}$ Many became leading lights in the fields of medicine, law, engineering, and education including Ivan Allen [9], New Zealand's first consultant neurologist; Ivor Prichard [183=], a Chief Judge of the Māori Land Court; Edgar McKillop [143=], OBE, and Permanent Head of the Public Works Department; and Hugh Crawford Somerset [499=], an "outstanding figure in New Zealand adult education" and co-author of the famous "Littledene" study. ${ }^{103}$ Other leaders in education were John Schroder [73=], Douglas Ball [114=], Norman Richmond [224=], and Allan Kirk [479=]. ${ }^{104}$ Norman Jory [44], Louis Bennett [411=], and William Cotter [499=] provided leadership in medicine. ${ }^{105}$ Leopold de Roo [5], Abram Hudson [51=], Gordon Reed [80=], Albert Grigg [102=], George Battersby [127=], Ramsay Winter [191=], Horace Lusty [250=], Theodore Gibbs [363=], Frederick Hanson [431=], and Cedric White [577=] were important figures in their professions. ${ }^{106}$ Brian Hewat [4] became Mayor of Invercargill during the 1950s, and two others represented their areas in local body politics. ${ }^{107}$ Fifty percent of the men were categorised as professionals, semi-professionals, or leaders of large organisations. Based on occupational status alone, they can be counted as having achieved some degree of success, irrespective of what may have happened later, occupationally, and the success or otherwise of other aspects of their lives. When white-collar workers are included, the percentage of those in higher status occupations rises to 72 percent. ${ }^{108}$ And who is to say that many of the remainder-including farmers, skilled workers, and small business people-were not also successful in their own fields.

The range of opportunities available to women was much narrower. Women were largely expected to marry and raise a family. To continue working was seen as both slighting their husband's ability to support a family and taking work from a man. Dorothy Hardcastle [1] achieved a Master of Arts degree with honours in literature and languages at Canterbury College, and then 
taught for several years at Timaru Girls' High School. But when Dorothy married a farmer in 1925 she immediately gave up her employment, as was expected of married women. ${ }^{109}$ Two women with long-term teaching careers took advantage of overseas exchange opportunities. Doris McKenzie [307=], the home science mistress at Waitaki Girls' High School, travelled to Scotland in 1931 on a year-long exchange, and in 1935 Ruby Milnes [458=] of Levin District High School went on a teaching exchange to South Africa. ${ }^{110}$ Later in life Doris McKenzie became an inspector of schools. ${ }^{111}$ High achieving women in the group included doctor Grace Kime [28=] and Otago University senior lecturer Mary Turnbull [33=], ${ }^{112}$ as well as Elizabeth Gibson $[261=]$, ${ }^{113}$ who was elected President of the New Zealand branch of the Women's International League for Peace and Freedom. There may have been others with noteworthy achievements but under their married names.

In light of their later educational and occupational accomplishments, the potential of the junior scholarship candidates as future high achievers seems clear. But was it recognised at the time of this, probably first, public examination success? No endorsements of individual or collective excellence were discovered in newspapers at the time the list of candidates was published. Apart from those for whom we know something of their careers, there was newspaper testimony regarding the few whose lives were cut short at an early age. Horace Larking [111=] was "an exceptionally smart boy [who] promised to have a very successful career." 114 Keith Douglas [465=], who died one month short of his fourteenth birthday, was "a very clever lad ... and gave every promise of a successful future." 115 An early and accidental death befell one of the girls also. Clarice Gedney [620=] died in a railway platform accident in 1912 while in her mid teens. Extolled as "a girl of splendid promise," Clarice had won a junior scholarship to attend high school in spite of a "short preparation," and went on to pass the Junior Civil Service Examination. ${ }^{116}$ While Clarice and Keith still attended school and Horace was in the early stages of an engineering career with the Public Works Department, they were regarded as young people of great potential. It seems likely that all 645 candidates who passed the examination would have been considered among the brightest of their age group and, the boys especially, destined for successful careers.

Although many candidates achieved success across a range of spheres, some lives turned out less fortunately. Sometimes this was simply a matter of bad luck. Apart from those already mentioned, 11 others died while still fairly young. Some of these deaths resulted from accidents, such as linesman Eric Hall [420=], who fell from a ladder in 1925 in the course of his work; surveyor Arnold Parkinson [613=], who died in 1930 after a motorcycle crash; and engineer John Deem [121=], who died while on holiday at Mount Ruapehu in 1933. ${ }^{117}$ Others died from illnesses or unknown causes. ${ }^{118}$ Clinton Gribbin [601=], a teacher, used poison to commit suicide in $1937 .{ }^{119}$ Three candidates were declared insolvent and two suffered bankruptcies; two of these cases occurred during the late 1920s and early 1930s. ${ }^{120}$ Sports dealer Ernest Gilmour [601=] was convicted of forgery and theft in 1927 and jailed for three years. A second stint in prison followed in 1935 when he was found guilty of false pretenses and conspiracy to defraud, this time for four years with hard labour. ${ }^{121}$ Accountant John Stevens [134=] was convicted in 1928 of forging a timber royalty receipt. ${ }^{122}$ In the same year, solicitor Hector Malcolm [595=] stole $£ 8,000$ from a trust account and fled to Australia. He was struck off and bankrupted but appears to have evaded capture. Coincidentally, the lawyer representing Malcolm's main creditors, Mr W.H. Cocker, may have been another of the scholarship candidates, William Hollis Cocker [45=], who also practised law. ${ }^{123}$ Finally, Clutha Mackenzie [57=] was charged in 1938 with the indecent assault of eight males at the Jubilee Institute for the Blind where he was Director, though the charges were 
dismissed in court. Despite what surely must have been a scandal, little evidence was found in the available newspapers, merely one article prior to the trial, and four concerning Mackenzie's later resignation. ${ }^{124}$ Even before the dismissal of the charges, perhaps Mackenzie's knighthood, awarded in 1935 for services to the blind, and the widespread high regard in which he was held had a protective effect and led to restrained newspaper coverage. Economic difficulties during the Depression and the earlier New Zealand downturn may have been a contributing factor in some candidates' insolvencies and bankruptcies, their individual misfortunes not wholly of their own making. But those convicted of forgery, fraud, false pretenses, and theft took advantage of positions of trust. Despite receiving the benefits of higher education, the scholarship candidates could be subject to temptation, dishonesty, and weakness of character much as found throughout the general population.

With the availability of searchable online archival sources it has been possible to trace, to some degree, many of the young people listed in the 1909 Gazette and their participation in higher education and the workforce. While the database searches provided more detailed results for boys, the data found on the girls showed the growing importance of secondary and tertiary education for girls. In line with Olssen and Hickey's observations, academically able young women overwhelmingly chose the semi-professional status of teaching as their best option among the narrow range of acceptable female occupations. The scholarship candidates' early strivings for success placed them on the ladder of educational, occupational, and social mobility. Most appear to have moved upward but just as Nolan warned of the need for awareness that mobility was not always positive, a few slipped down. Overall though, a high proportion attended university and engaged in higher status occupations. The First World War was an unparalleled disruption to the lives of all New Zealanders and a significant number of promising young men were killed or otherwise adversely affected by the war. The 56 men who died while serving their country underline the magnitude of New Zealand's loss of so much talent and energy. Many young people with intelligence and drive took advantage of the chances offered by national scholarships, continuing their education through secondary school, university, and vocational opportunities. But luck also played a part. For some, the early boost of scholarship success was derailed by war and the Depression, poor choices, or by random misfortune. Seddon intended the Junior National Scholarships to be instrumental in producing New Zealand leaders and "master minds," but, although comparatively few of the candidates engaged in commerce and politics as he had envisaged, the array of doctors, engineers, legal professionals, public servants, and teachers provided leadership in their areas of expertise and no doubt in the community also. It would be interesting to compare this cohort with those of earlier and later years to see whether their level of participation in tertiary study and career profiles were typical. While only a tiny fragment of the 1908 scholarship candidates' lives has been revealed, it shows that, overall, these members of the younger generation of the First World War years fulfilled their potential abundantly.

\footnotetext{
${ }^{1}$ G Hogben, "Report on Annual Examinations", 3 August 1909, Appendix to the Journals of the House of Representatives (AJHR), 1909, I, E-8, 2. Of the 1,765 children who sat the examination, 1,304 were aiming to win a scholarship and a free place at a secondary school while 461 aimed for just the free place. ${ }^{2}$ The main source of dates of birth was those military personnel files viewable via Archives New Zealand's Archway database.

${ }^{3} A J H R, 1909$, II, E-2, 15. Fifty-four percent of boys and 53 percent of girls.
} 
${ }^{4}$ Statistics New Zealand, New Zealand Official Year Book 1910, table: “Age and Sex of Pupils, December 1908", "Secondary Education", http://www.stats.govt.nz/yearbooks\#NZ\%20Official\%20yearbooks; Statistics New Zealand, New Zealand Official Year Book 2012, table: "Education, 1875-2012",

http://www.stats.govt.nz/browse_for_stats/snapshots-of-nz/yearbook.aspx. Secondary schools included district high schools, technical schools, and Māori denominational boarding schools. By 1950, 15 percent of school-children were secondary school pupils. In 2010, the percentage of secondary pupils had reached 42 percent.

${ }^{5}$ AJHR, 1909, II, E-6, 10-11.

${ }^{6}$ National Scholarships Act 1903; E.J. Parr, "The Expansion of Secondary Education”, in Fifty Years of National Education in New Zealand, 1878-1928, ed. I Davey (Auckland: Whitcombe and Tombs Ltd, 1928), 76.

${ }^{7}$ Richard Seddon, 1906, quoted in James Drummond, Life and Work of Richard John Seddon, Premier of New Zealand, 1893-1906, with a History of the Liberal Party (Christchurch: Whitcombe and Tombs, 1907), 362.

${ }^{8}$ David Hamer, "Seddon, Richard John", from the Dictionary of New Zealand Biography. Te Ara - the Encyclopedia of New Zealand, updated 12 February 2014, http://www.teara.govt.nz/en/biographies/2s11/seddon-richard-john.

${ }^{9}$ New Zealand Gazette, 28 January 1909, no. 6, 269-72; AJHR, 1909, II, E-8, 4-7.

${ }^{10}$ Melanie Nolan, "Constantly on the Move but Going Nowhere? Work, Community and Social Mobility," in The New Oxford History of New Zealand, ed. Giselle Byrnes (South Melbourne: Oxford University Press, 2009), 378.

${ }^{11}$ Seddon, quoted in Lyttleton Times, 18 December 1899, quoted in Ian McLaren, "The Politics of Secondary Education in Victorian New Zealand," in Reinterpreting the Educational Past: Essays in the History of New Zealand Education, eds. Roger Openshaw and David McKenzie (Wellington: NZCER, 1987), 75.

${ }^{12}$ McLaren, "The Politics of Secondary Education in Victorian New Zealand," 72-5.

${ }^{13}$ Roger Openshaw, Greg Lee, and Howard Lee, Challenging the Myths: Rethinking New Zealand's Educational History (Palmerston North: Dunmore Press, 1993), 96-8, 100-7, 115-8; David McKenzie, Howard Lee, and Greg Lee, Scholars or Dollars? Selected Historical Case Studies of Opportunity Costs in New Zealand Education (Palmerston North: Dunmore Press, 1996), 118-21, 134-6; Greg Lee and Howard Lee, Examinations and the New Zealand School Curriculum: Past and Present (Palmerston North: Department of Education, Massey University, 1992), 3-6.

${ }^{14}$ Most Native schools were opened in remote rural locations of high Māori population and were open to Pākehā pupils also. The denominational colleges were also open to Pākehā pupils.

${ }^{15}$ Openshaw, Lee, and Lee, Challenging the Myths, 66. The first state-run Māori District High School did not open until 1941.

${ }^{16}$ AJHR, 1901, E-1, iv; AJHR, 1901, E-2, 1; AJHR, 1909, E-1, 6; AJHR, 1909, E-3, 1.

${ }^{17}$ New Zealand Herald, 8 February 1906, 6.

${ }^{18}$ Eric Olssen, "Towards a New Society", in The Oxford History of New Zealand, 2nd ed, ed. Geoffrey W Rice (Auckland: Oxford University Press, 1992), 276; Erik Olssen, "Working Gender, Gendering Work: Occupational Change and Continuity in Southern Dunedin," in Sites of Gender: Women, Men and Modernity in Southern Dunedin, 1890-1939, eds. Barbara Brookes, Annabel Cooper, and Robin Law (Auckland: Auckland University Press, 2003), 52, 71-2, 75, 77, 80.

${ }^{19}$ Melanie Nolan, Breadwinning: New Zealand Women and the State (Christchurch: Canterbury University Press, 2000), 36.

${ }^{20}$ Margaret Tennant, "Natural Directions: The New Zealand Movement for Sexual Differentiation in Education during the Early Twentieth Century", in Women in History: Essays on European Women in New Zealand, eds. Barbara Brookes, Charlotte Macdonald, and Margaret Tennant (Wellington: Allan \& Unwin, 1986), 89-90, 92-4. 
${ }^{21}$ Kay Morris Matthews, In Their Own Right: Women and Higher Education in New Zealand before 1945 (Wellington: NZCER Press, 2008), 23-4.

${ }^{22}$ Tanya Fitzgerald and Jenny Collins, Historical Portraits of New Zealand Home Scientists: The University of New Zealand, 1911-1947 (Amherst: Cambria Press, 2011).

${ }^{23}$ Erik Olssen, Building the New World: Work, Politics and Society in Caversham 1800s-1920s (Auckland: Auckland University Press, 1995), 16.

${ }^{24}$ Nolan, "Constantly on the Move", 378.

${ }^{25}$ For some names no results were found. This could mean that the individual was not a New Zealand serviceman, that the name entered was misspelled or incorrect in some way, or that information on that person had not yet been uploaded to the database.

${ }^{26}$ For example, killed in action, died of wounds, or died of disease.

${ }^{27}$ David Hood, "Past Lessons: Best Practice in Quantitative Historical Research", in Class, Gender and the Vote: Historical Perspectives from New Zealand, eds. Miles Fairburn and Erik Olssen (Dunedin:

University of Otago Press, 2005), 217.

${ }^{28}$ See, for example, Capital and Coast District Health Board, "Ivan MacDonald Allen," http://www.ccdhb.org.nz/hhist/staff/AllenIM N.html (accessed 5 January 2014).

${ }^{29}$ National Scholarships Act 1903, s.3.

${ }^{30}$ AJHR, 1909, II, E-6, 4.

${ }^{31}$ Marlborough Express, 19 June 1909, 3.

${ }^{32}$ Evidence of R.E. Rudman, E. Pinder, C.R.D. Richardson, and F.T. Evans, AJHR, 1912, II, E-12, 116, $219,221,253,389$.

${ }^{33}$ The nine, with their 1908 and 1909 scores, were: Doris McClurg [from 430= to 3]; John Steven [from $467=$ to 8]; Ivan Allen [from 349= to 9]; John Dickinson [from 146= to 10]; Herbert Kemp [from 340= to $11=$ ]; Edith McKenzie [from 393= to 14]; Michael O'Connor [from 471= to 17=]; and John Iverach [from $136=$ to 20]. At least another 40 appeared on both the 1908 and 1909 lists: New Zealand Gazette, 30 January 1908, no.8, 395-99.

${ }^{34}$ Timaru Herald, 21 January 1909, 7. Third-placed Doris McClurg was likewise unable to receive a national scholarship.

${ }^{35}$ Evidence of F.T. Evans, AJHR, 1912, E-12, 389. Pupils from country schools were thought to be at a disadvantage because it was very difficult for the teacher, and possibly the pupils also, to devote time to an "extended programme" of additional study.

${ }^{36}$ See Dictionary of New Zealand Biography entries for Theodore Gibbs, Frederick Hanson, Hugh Somerset, Douglas Ball, Graham Parkinson, Howard Kippenberger, Leonard Bestall, Clutha Mackenzie, and Norman Richmond; for Elizabeth Gibson, see the entry for her mother, Emily Gibson. For Horace Larking, see Auckland Star, 16 May 1916, 2; for Harold Bennetts, see Otago Daily Times, 10 November 1914, 3; for Doris McClurg, see Ashburton Guardian, 14 February 1906, 2; 31 July 1908, 3; and 4 March 1909, 2; for Richard Kinloch, see New Zealand Herald, 2 June 1920, 8; for Effie Cathie, see Evening Post, 11 April 1906, 2, and 3 September 1931, 8.

${ }^{37}$ See, for example, these editions of the Observer: 13 July 1909, 8; 2 September 1911, 8; 7 December 1912, 8; and 17 April 1915, 8; Auckland Star, 2 September 1925, 17. Miss Whitelaw and other family members also attended a garden party at Buckingham palace in 1925.

${ }^{38}$ Parr, "The Expansion of Secondary Education", 76.

${ }^{39}$ Dominion, 16 February 1910, 4; Evening Post, 15 February 1910, 7; Oamaru Mail, 31 August 1910, 4; Timaru Herald, 3 October 1910, 7. The Education Amendment Act 1910 omitted the parental income qualification and opened up scholarships to pupils at private schools.

${ }^{40}$ Family history web pages were used only when they provided other corroborating details in keeping with what was known already about a person.

${ }^{41}$ Archway military personnel file for Vivian Barton; Nelson Evening Mail, 23 January 1909, 2.

${ }^{42}$ Denis McLean, Howard Kippenberger, Dauntless Spirit: A Life of an Outstanding New Zealand Leader (Auckland: Random House, 2008), 19, 22, 24-5. Also see Glyn Harper, "Kippenberger, Howard Karl," 
from the Dictionary of New Zealand Biography. Te Ara - the Encyclopedia of New Zealand, updated 30 October 2013, http://www.teara.govt.nz/en/biographies/5k11/kippenberger-howard-karl.

${ }^{43}$ Otago Daily Times, 31 October 1914, 3; AJHR, 1924, I, E-2, appendix E, lxxiii; probate file for Karl Henry Kippenberger, Archway database, Archives New Zealand.

${ }^{44}$ McLean, Howard Kippenberger, 19; Cenotaph and Archway databases; Harper, "Kippenberger, Howard Karl." Howard Kippenberger's date of birth was 28 January 1897. That makes him a little on the young side of the cohort of 105 boys for whom dates or years of birth are known, but four others were younger.

${ }^{45}$ Kay Morris Matthews, In Their Own Right, 28-30. Morris Matthews described the challenges involved in trying to trace the careers of women university graduates.

${ }^{46}$ Erik Olssen, "Women, Work and Family: 1880-1926," 173.

${ }^{47}$ Evening Post, 11 June 1925, 13; Evening Post, 30 November 1925, 13; Auckland Star, 2 December 1925, 1. The weddings of Dorothy Hardcastle [1] and Grace Kime [28=] were described in detail: clothes, flowers, members of the bridal party, gifts exchanged, and the motoring holidays planned for the newly married couples.

${ }^{48}$ New Zealand War Graves Trust, "Harlequin Gladstone Huxtable," http://www.nzwargraves.org.nz/casualties/harlequin-gladstone-huxtable (accessed 5 January 2014); Ministry for Culture and Heritage, "New Zealand and the First World War", updated 19 November 2013, http://www.nzhistory.net.nz/war/first-world-war-overview/introduction; Australian War Memorial, First World War embarkation roll, Australian Imperial Force nominal roll, 97, http://www.awm.gov.au/collection/records/awm8/23/30/awm8-23-30-4-0098.pdf (accessed 5 January 2014). Harlequin Huxtable, killed in action in August 1918, was one of over 3,000 New Zealanders to serve in the Australian or British armies.

${ }^{49}$ For Eric Battershill, see Auckland Star, 4 June 1928, 3. For Norman Gadsby, see Hawera \& Normanby Star, 1 May 1915, 4; Auckland Star, 19 January 1922, 7; Auckland Star, 21 March 1934, 6.

${ }^{50}$ AJHR, 1909, II, E-7, 3; AJHR, 1916, II, E-7, 31; AJHR, 1920, I, E-7, 29.

${ }^{51}$ That is, seven from among the 80 who attended university. See Archway, Cenotaph, Papers Past, and Tapuhi databases; Dictionary of New Zealand Biography entries for Muriel H. Deem (wife of John S.L. Deem [121=]), Graham B. Parkinson [166=], Norman M. Richmond [224=], and Theodore N. Gibbs [363=]; http://www.ccdhb.org.nz/hhist/staff/AllenIM N.htmld - Ivan M. Allen [9]; Ministry for Culture and Heritage, "Hazelburn district war memorial," updated 15 July 2013, http://www.nzhistory.net.nz/media/photo/hazelburn-district-war-memorial - Michael B. O'Connor [17=]; Ministry for Culture and Heritage, "Expatriates - Biographies: United Kingdom," from A.H. McLintock (ed.), An Encyclopaedia of New Zealand, originally published 1966, updated 22 April 2009, http://www.teara.govt.nz/en/1966/expatriates-biographies/page-32 - Norman A. Jory [44] and Ramsay M. Winter [191=]; New Zealand Society of Soil Science, "A History of Soil Survey and Selected Aspects of Soil Conservation in NZ, Part One", in Soil News 55, no. 2 (April 2007) - Abram W. Hudson [51=]; http://www.gw.govt.nz/assets/Our-Environment/Water-Supply/PDFs/1940s-1970s-Regional-water-waterhistory.pdf (accessed 6 January 2014) - Edgar R. McKillop [143=]; http://www.justice.govt.nz/courts/maori-land-court/about-us/our-judges-1/past-mlc-judges (accessed 6 January 2014) - Ivor G. Prichard [183=]; McLean, Howard Kippenberger, 103 - Harry S. Baverstock [448=]; Archives New Zealand, "Cotter, William Makuri, 1894-1980,” updated 2 June 2009, http://thecommunityarchive.org.nz/node/74430 - William M. Cotter [499=].

${ }^{52}$ See AJHR reports on higher education: 1913, E-7, 4; 1914, E-7, 4; 1915, E-7, 4; 1916, E-7, 31; 1917, E-7, 24; 1918, E-7, 28; 1919, E-7, 28; 1920, E-7, 29.

${ }^{53}$ Beryl Hughes and Sheila Ahern, Redbrick and Bluestockings: Women at Victoria 1899-1993 (Wellington: Victoria University Press, 1993), 43. During 1918 more than half the students at Victoria University College were women: 198 women and 166 men.

${ }^{54}$ The MA degree-holders were Dorothy Hardcastle [1], Johanna Brosnan [22], Mary Turnbull [33=], Evangeline Anderson [36], Winifrid Farnie [41=], Lydia Oldridge [61], Alice Cocker [62=], Elsie Hall [123=], Laura Sheat [197=], Dorothy Bingham [307=], Irene Phillips [376=], and Agnes Pigou [494]. 80 Journal of New Zealand Studies NS18 (2014), 66-84 
The MSci degree-holders were Valeria Johnson [73=] and Enid Cauty [479=]. Cauty's degree was in Home Science; Johnson's may have been also. There were also 10 with a BA degree and 1 BSc.

${ }^{55}$ Ruth Fry, It's Different for Daughters: A History of the Curriculum for Girls in New Zealand Schools, 1900 - 1975 (Wellington: New Zealand Council for Educational Research, 1985), 73 tbl.

${ }^{56}$ Erik Olssen and Maureen Hickey, Class and Occupation: The New Zealand Reality (Dunedin: University of Otago Press, 2005), 132, 155-252.

${ }^{57}$ See Archway, Cenotaph, Papers Past, and Tapuhi databases. John Iverach [20], for example, began his career teaching but changed to medicine after the First World War.

${ }^{58}$ Nolan, Breadwinning, 36. Known as the "white blouse" revolution, the percentage of women engaged in office work rose from two percent in 1890 to 40 percent in 1939.

${ }^{59}$ Sandra Coney, Standing in the Sunshine: A History of New Zealand Women since they Won the Vote (Auckland: Penguin Books, 1993), 228.

${ }^{60}$ Olssen, "Women, Work and Family", 165.

${ }^{61}$ Ibid., 161, 163-4 tbl 8.3. In 1921, New Zealand's female labour force included 7,637 school teachers, around 1,000 music teachers, 13,425 office workers, 17,955 domestics, 5,212 housekeepers and maids, 13,841 clothing workers, 9,229 shop workers, 3,020 waitresses, 2,227 barmaids, 4,393 nurses, and 34 doctors.

${ }^{62}$ Tanya Fitzgerald, Outsiders or Equals? Women Professors at the University of New Zealand, 1911 1961 (Oxford: Peter Lang, 2009), 18.

${ }^{63}$ Auckland Star, 18 June 1926, 5. Grace Kime, who by this time had married and was known as Dr Grace Proude, gave evidence in a court case between Dr R.J. Boyd and the Wanganui Hospital Board over nonpayment of Dr Boyd's fees. As medical superintendent of Waimarino Hospital, near Raetihi, she said the Wanganui board knew that "she would have to get outside help."

${ }^{64}$ Olssen and Hickey, Class and Occupation, 76.

${ }^{65}$ Michael Belgrave, "A Subtle Containment: Women in New Zealand Medicine, 1893-1941”, New Zealand Journal of History 22, no. 1 (1988): 48-51.

${ }^{66}$ Hughes, "Women and the Professions in New Zealand", 120. See also Morris Matthews, In Their Own Right, 31 .

${ }^{67}$ Coney, Standing in the Sunshine, 206.

${ }^{68}$ Ibid., 193.

${ }^{69}$ Averille Lawrence, Lively Retrospect: Timaru Girls' High School, 1880-1980 (Timaru: Centennial Committee, Timaru High School Old Girls' Committee, 1980), 35, 46.

${ }^{70}$ See Archway for probates or Auckland Education salary cards for: H. Paterson [2]; W. Farnie [41=]; E. Houghton [75=]; F. Davies [282=]; O. Cowley [286=]; D. McKenzie [307=]; L. Humphreys [328=]; E. Chillingworth [342=]; I. Phillips [376=]; A. Hilliard [431=]; E. Young [439=]; R. Milnes [458=]; R. James [487=]; E. Bayne [553=]; for Bella Grey (née Craig) [549=], see Auckland Star, 19 March 1929, 9. The nine who began teaching when they left school, but whose probate occupation was "spinster," were E. Pay [156=], L. Sheat [197=], R. Jull [261=], D. Bingham [307=], M. Bollinger [318=], A. Gernhoefer [376=], I. Ferguson [424=], A. Glanville [522=], E. Rohan [522=].

${ }^{71}$ Auckland Star, 19 March 1929, 9. Bella Craig [549=] was an "exceedingly popular" schoolteacher whose many abilities were "fully appreciated" by the Manurewa community. When she died in 1929 after a brief illness her funeral was attended by leading members of the community and representatives of many local organisations. More than 100 schoolchildren formed a guard of honour for the funeral cortege of 50 cars.

${ }^{72}$ See Archway, Cenotaph, Papers Past, and Tapuhi databases, as well as the DNZB entries and web pages listed for note 51. Figures have been rounded. The other professionals were military officers, university professors or lecturers, chemists, one research scientist, and one dentist. Also included were law clerks, surveyors' assistants, medical students, and other students where there was no further evidence of their work history (sometimes because they had died during the First World War), because the initial direction was often highly indicative of longer-term intentions. 
${ }^{73}$ See Archway, Cenotaph, Papers Past, and Tapuhi databases, as well as the DNZB entries and web pages listed for note 51 .

${ }^{74}$ Olssen and Hickey, Class and Occupation, 101 tbl 4.3.

${ }^{75}$ The 264 are those occupations could be placed in Olssen and Hickey's categories 01 to 09.

${ }^{76}$ Olssen and Hickey, Class and Occupation, 101 tbl 4.3.

${ }^{77}$ Michael King, The Penguin History of New Zealand (Auckland: Penguin, 2003), 346; Finance (No 2)

Act 1931, s 35. In response to a severe drop in revenue the Government tried to cut costs wherever possible, and among the cost-cutting measures was the abolition of junior and senior national scholarships. Scholarships already awarded remained in effect.

${ }^{78}$ Auckland Star, 16 March 1929, 12.

${ }^{79}$ Keith Rankin, "How Great was the Depression in New Zealand? Neglected Estimates of Inter-war Aggregate Income: Comment," New Zealand Economic Papers 28, no. 2 (1994): 206.

${ }^{80}$ Auckland Star, 16 March 1929, 12.

${ }^{81}$ Grey River Argus, 11 August 1914, 5.

${ }^{82}$ Ministry for Culture and Heritage, "New Zealand and the First World War."

${ }^{83}$ See Cenotaph and Archway military personnel files for N. Mackenzie [7], R. Harris [13], A. Taylor [16], M.B. O'Connor [17=], A.S. Hewat [19], S.C. McCarthny [25=], W.H. Morris [75=], J.A. Wilson [95=], D.P.B. Hosie [97], F.R. Cummin [98=], S.R. Ellis [102=], A.J. McCaw [102=], G.L. McCabe [105=], L.A. O'Leary [120], J.M. Glasgow [146=], H.S.M. Sanson [180=], J. Harper [183=], J. Catto and H.L. Wake [191=], F.A. Crum [204=], G.T. Cox and A.J. Wyatt [239=], A.R. Douglas [255=], P.S. Livermore [261=], A.L. Throp [269=], D.H. Craig and J.W. Omand [276=], I.B. Baxter [321=], F.C. Matthews [332=], R.E. Kelly [338=], C.B. McArthur [355=], A.C. Boyd [368=], W.E. Stevens [373=], H.O. Rosevear [384=], H.P. Laws [388=], J.K. Cresswell [403=], O.J. Smith [411=], O.D. Pearce [431=], E.J. Miller and F.D. Perrin [444=], W. Knuckey [448=], E.Q. Low [465=], P.C.M. Powell and S.O. Reynolds [471=], F.M. Jenkins [479=], H. Ayling and E.H. Walker [499=], J.V. Cooper [512=], K.S. Abernethy [526=], J.R.R. Leys [532=], S.H. Parsons [546=], H.C. Eriksen [549=], J.H. Wright [569=], H.G. Huxtable [595=], and W.L. McMurray [629=]. For R.A. Mackay [342=] see Press, 10 June 1919, 1. ${ }^{84}$ W.S. Broughton, "Mackay, Charles Ewing," from the Dictionary of New Zealand Biography. Te Ara the Encyclopedia of New Zealand, updated 12 November 2013, http://www.teara.govt.nz/en/biographies/3m14/mackay-charles-ewing; Helen McCracken, "Sarjeant Gallery," updated 24 September 2001, http://www.historic.org.nz/TheRegister/RegisterSearch/RegisterResults.aspx?RID=167.

${ }^{85}$ Wanganui Herald, 20 May 1909, 7.

${ }^{86}$ Otago Daily Times, 10 November 1914, 3; Evening Post, 11 November 1914, 3.

${ }^{87}$ Auckland Star, 16 May 1916, 2; New Zealand Herald, 17 May 1916, 6; Wanganui Chronicle, 15 May 1917, 4.

${ }^{88}$ Wanganui Chronicle, 1 June 1912, 5; Colonist, 3 June 1912, 5; Auckland Star, 11 August 1924, 7; New Zealand Herald, 12 August 1924, 6. A one-armed man named Frank Carson died from suspected heart failure in 1924 while working as a rabbiter at Waiuku.

${ }^{89}$ Otago Daily Times, 2 October 1917, 7; Southland Times, updated 17 July 2010, http://www.stuff.co.nz/southland-times/news/features/southern-military-history/3918683/Brothers-inarms.

${ }^{90}$ Poverty Bay Herald, 9 August 1917, 4.

${ }^{91}$ Penelope Hansen, "Mackenzie, Clutha Nantes," from the Dictionary of New Zealand Biography. Te Ara - the Encyclopedia of New Zealand, updated 12 November 2013, http://www.teara.govt.nz/en/biographies/4m17/mackenzie-clutha-nantes.

${ }_{92}$ Military personnel file for Harold Louis Possenniskie, Archway database, Archives New Zealand; Auckland Star, 2 June 1920, 4; Evening Post, 5 September 1933, 9; Press, 1 October 1918, 8. Those affected by gas poisoning included Harold Possenniskie [39], Richard Kinloch [70=], Alfred Booth [428=], and Leslie Mably [439=].

${ }^{93}$ Military personnel file for Clarence Valentine Jackman, Archway database, Archives New Zealand. 82 Journal of New Zealand Studies NS18 (2014), 66-84 
${ }^{94}$ Military personnel file for Thomas Freebury Gardiner Wilson, Archway database, Archives New Zealand; Evening Post, 1 June 1923, 1.

${ }^{95}$ Military personnel file and probate for Allan Edward Macfarlane, retired accountant, Rotorua, 1979, Archway database, Archives New Zealand. Prior to the war, Macfarlane had farmed; following his rehabilitation he retrained as an accountant.

${ }^{96}$ Military personnel file and probate for Vincent Gordon Jervis, retired army officer, Wellington, 1973, Archway database, Archives New Zealand; Evening Post, 8 March 1927, 11; Evening Post, 6 April 1939, 7.

${ }^{97}$ Evening Post, 14 August 1913, 10.

${ }^{98}$ Otago Daily Times, 24 January 1914, 12; Press, 24 January 1914, 14.

${ }^{99}$ Ellesmere Guardian, 22 June 1928, 2.

${ }^{100}$ Daily Herald (Adelaide), 27 November 1922, 4; Ellesmere Guardian, 22 June 1928, 2; Auckland Star, 4 June 1928, 3; Sydney Morning Herald, 29 December 1954, 6, 18.

${ }^{101}$ Harper, "Kippenberger, Howard Karl"; J.A.B. Crawford, "Parkinson, Graham Beresford", from the Dictionary of New Zealand Biography. Te Ara - the Encyclopedia of New Zealand, updated 7 January 2014, http://www.teara.govt.nz/en/biographies/5p12/parkinson-graham-beresford.

102 Hansen, "Mackenzie, Clutha Nantes."

${ }^{103}$ Ministry for Culture and Heritage, "Littledene", updated 18 June 2013, http://www.nzhistory.net.nz/media/photo/littledene.

${ }^{104}$ See Dictionary of New Zealand Biography entries for Douglas G. Ball [114=] and Norman M. Richmond [224=], and Tapuhi entries for John H.E. Schroder [73=] and Allan A. Kirk [479=].

${ }^{105}$ For Norman A. Jory [44] see http://www.teara.govt.nz/en/1966/expatriates-biographies/page-32; for Louis A. Bennett [411=] see Archives New Zealand, “Bennett, Louis Amos, 1896-1979”, updated 2 June 2009, http://thecommunityarchive.org.nz/node/74404; for William M. Cotter [499=] see http://thecommunityarchive.org.nz/node/74430.

${ }^{106}$ See Dictionary of New Zealand Biography entries for Theodore Gibbs [363=] and Frederick M.H. Hanson [431=], and Tapuhi entries for Leopold R. de Roo [5] and Cedric W. White [577=]. For Abram W. Hudson [51=], see New Zealand Society of Soil Science, "A History of Soil Survey", Soil News 55, no. 2 (April 2007): 69-70; for Albert J. Grigg [102=], see Auckland Star, 21 December 1938, 14; for Gordon J. Reed [80=], see Evening Post, 24 October 1940, 13; for George H. Battersby [127=], see Pipes \& Wires 58 (2007), http://www.utilityconsultants.co.nz/library/pnw/pipeswires58.htm; for Ramsay M. Winter [191=], see http://www.teara.govt.nz/en/1966/expatriates-biographies/page-32; for Horace C. Lusty [250=], see http://www.ipenz.org.nz/heritage/bio-details.cfm?id=45 (accessed 6 January 2014).

${ }^{107}$ For Brian W. Hewat [4], see Kete Invercargill, "BW Hewat", updated 5 December 2012, http://keteinvercargill.peoplesnetworknz.info/kete_invercargill/images/show/188-b-w-hewat. For Victor E. Jacobson [160=], see Evening Post, 2 May 1929, 14; Auckland Star, 26 October 1935, 16. For Roderick W. Toomath [255=], see Evening Post, 22 August 1936, 3.

${ }^{108}$ The percentages are based on a group of 315 males. From the 330 males, 15 were removed because they had died, most during the war, without any occupational information having been found about them. The 15 were Wilson [95=], Ellis [102=], McCaw [102=], Glasgow [146=], Wake [191=], Crum [204=], Wyatt [239=], Kelly [338=], Mackay [342=], Laurenson [424=], Douglas [465=], Reynolds [471=], Jenkins [479=], and Eriksen [549=].

${ }^{109}$ Press, 11 June 1925, 13; Lawrence, Lively Retrospect, 35, 46.

${ }^{110}$ Auckland Star, 18 June 1931, 12; Evening Post, 9 February 1935, 6; Evening Post, 9 September 1936, 17.

${ }^{111}$ See probate for Doris Hazel McKenzie, inspector of schools, Mahina Bay UK/Christchurch, 1975, Archway database, Archives New Zealand.

${ }^{112}$ Fitzgerald, Outsiders or Equals?, 18. 
${ }^{113}$ Megan Hutching, "Gibson, Emily Patricia," from the Dictionary of New Zealand Biography. Te Ara the Encyclopedia of New Zealand, updated 30 October 2012,

http://www.teara.govt.nz/en/biographies/3g7/gibson-emily-patricia; Melanie Nolan, "'Politics Swept

Under a Domestic Carpet?': Fracturing Domesticity and the Male Bread-winner Wage: Women's

Economic Citizenship, 1920s - 1940s", New Zealand Journal of History 27, no. 2 (1993): 212. Elizabeth

Ray Gibson, later known as Ray Wynn, was the daughter of Emily Gibson, "feminist, socialist,

internationalist," who was strongly involved with the Auckland Women's Political League, the New

Zealand branch of the Women's International League for Peace and Freedom, and with the Labour Party.

${ }^{114}$ Hawera \& Normanby Star, 18 May 1916, 4.

115 Wanganui Herald, 20 May 1909, 5, 7.

${ }^{116}$ Poverty Bay Herald, 30 March 1912, 5; Otago Daily Times, 6 April 1912, 8.

${ }^{117}$ Auckland Star, 14 January 1925, 9; Auckland Star, 8 March 1930, 11; Linda Bryder, "Deem, Muriel Helen," from the Dictionary of New Zealand Biography. Te Ara - the Encyclopedia of New Zealand, updated 7 June 2013, http://www.teara.govt.nz/en/biographies/5d14/deem-muriel-helen.

${ }^{118}$ Others who died early were Victor Honeyfield [629=] in 1916; Isabel Haigh [458=] in 1919; Flight Lieutenant Henry Grout [197=] of the Royal Air Force in 1922; one-armed rabbiter Francis Carson [114=] in 1924; teachers Archibald Francis [349=] in 1924, Bella Craig [549=] in 1929, and Vivian Barton [261=] in 1934; and clerk Alfred Booth [428=] in 1933. Regarding Victor Honeyfield, see probate for Victor Maurice Honeyfield, Wellington, 1916, Archway database, Archives New Zealand; Press, 14 September 1916, 1. For Isabel Haigh, see Wairarapa Daily Times, 15 December 1919, 5. For Henry Grout, see probate for Henry Cranston Grout, 1922, Archway database, Archives New Zealand. For Francis Carson, see Auckland Star, 11 August 1924, 7. For Archibald Francis, see probate for Archibald Gordon Francis, Auckland, 1925, Archway database, Archives New Zealand; New Zealand Herald, 8 November 1924, 1. For Bella Craig, see Auckland Star, 19 March 1929, 9. For Vivian Barton, see probate for Vivian Barton, schoolmaster, Wellington, 1934, Archway database, Archives New Zealand. For Alfred Booth, see probate for Alfred Normanby Booth, clerk, Wellington, 1933, Archway database, Archives New Zealand; Evening Post, 5 September 1933, 8.

${ }^{119}$ Auckland Star, 3 November 1937, 8.

${ }^{120}$ See Archives New Zealand's Archway database closed insolvency files for Ralph Forrest Craig and Frederick Longlands Craig, trading as Craig Bros, 1915; Ernest Hunter Barrett, 1918-1920; and Arthur Rex Grainger, 1929; also Leonard Jack Bary, bankrupt: notice of motion of release, Blenheim, 1933; and Algeon Harold Horner, bankruptcy file, Murupara, 1960-64; Auckland Star, 21 April 1915, 8. Ralph Craig [490=] was declared insolvent in 1915 aged 18 years. Ralph had set up in business as a draper with his brother in April 1914 but through ignorance and mismanagement the business had foundered with large debts a year later. Ernest Barrett [591=] was declared insolvent in 1918 and Arthur Grainger [423] in 1929. Those who underwent bankruptcy proceedings were sheep farmer Leonard Bary [302=] and clerk Algeon Horner [517=].

${ }^{121}$ See bankruptcy file for Ernest Mabin Gilmour, Invercargill, 1927, Archway database, Archives New Zealand; Evening Post, 3 November 1927, 24; 16 November 1927, 11; 29 May 1934, 9; 9 June 1934, 14; 11 October 1934, 14; 9 February 1935, 10.

${ }^{122}$ Evening Post, 10 January 1928, 9; New Zealand Truth, 26 January 1928, 9; Evening Post, 3 February 1928,9 .

${ }^{123}$ Evening Post, 4 December 1928, 11; Auckland Star, 4 December 1928, 9; Auckland Star, 20 December 1928, 10; Evening Post, 11 March 1929, 11.

${ }^{124}$ Auckland Star, 14 May 1938, 12; Evening Post, 14 September 1938, 15; Hansen, "Mackenzie, Clutha Nantes." 